\title{
Development of Recycled Style Sandals at the Youth Organization Community, Bojonghaleuang Village, West Bandung Regency
}

\author{
Wenny Anggraini Natalia ${ }^{1}$ \\ ${ }^{1}$ Diploma of Art and Design, Faculty of Art and Design, \\ Maranatha Christian University, Bandung, Indonesia \\ anggraini_wenny91@yahoo.com \\ Tan Indra Janti ${ }^{2}$, Lois Denissa ${ }^{3 *}$, Junnica Hakim Santoso ${ }^{4}$, Ayu Kartika Sari ${ }^{5}$, Jesslyn Ivana Kristi ${ }^{6}$ \\ ${ }^{2,3,4,5,6}$ Diploma of Art and Design, Faculty of Art and Design, \\ Maranatha Christian University, Bandung, Indonesia \\ y_thie67@yahoo.com, lois.denissa@art.maranatha.edu, 1861006@art.maranatha.edu, \\ 1861016@art.maranatha.edu, 1861001@art.maranatha.edu
}

(Received October 22, 2021, accepted February 07, 2022)

\begin{abstract}
This community empowerment activity was implemented at the initiative of the Karang Taruna community in Bojonghaleuang Village, West Bandung Regency. This activity was intended to provide briefing and creativity training for youth organizations so that they would develop creativity that can be developed into commodity product businesses that are needed by the community. Garment scraps, leftover production and sorting/rejects that are abundant in the city of Bandung require community cultivation. The method used was the cooperative demonstration and practical making of decorative sandals, following modules that were taught both online and onsite, and applied in practice. Then, the youth group can re-explore the sandal model in another form that is more attractive, according to creativity, and can then meet market tastes. This training has many benefits, namely developing youth creativity, increasing the value of the benefits of leftover fabrics or rejected products into commodities of economic value. The utilization of textile waste as a self-supporting commodity for Karang Taruna really helps improve environmental sustainability in the city of Bandung. As a result of this activity, the Karang Taruna community was very enthusiastic about doing the exercises, able to produce interesting sandal creations, even some youth organizations have received purchase orders from the surrounding community.
\end{abstract}

Keywords: creativity; creative entrepreneurial opportunities; style sandals; utilization of textile waste 


\section{Introduction}

Activities that can hone creativity and stimulate creativity are important and need to be continued for a better life in the future. Various creative activities should be introduced and applied to the younger generation (Lubart, 2016) and should even be continued until we are adults, without ever stopping. The World Economic Forum lists creativity as a top ability for employability in the next decades. The $21^{\text {st }}$-century school movement has identified creativity as one of four key abilities to be fostered throughout education. Consider now the different types of creative contribution and then the extent to which creativity can occur in many different domains (Lubart, 2016).

Creativity is needed in every field of life, at all ages, young and old, men and women need creativity to make life more meaningful. Creativity needs to be honed and stimulated in order to grow and develop properly so that its growth can be recognized and felt in people's lives. So indeed creativity cannot be developed or fostered alone, it must be fostered in the form of its integration with physical abilities and ratios in appreciation (Tabrani, 2006).

Another opinion says that creativity is something that is really needed by the community so that the needs of the community are considered in creative activities. Knowledge and materials owned by the community are the determinants of the production of creative products that contain novelty. Creative work tends to be useful for some groups, and thus that social judgment is involved; a creative insight arises from a reintegration of already existing materials or knowledge, but when it is completed, it contains elements that are new (Runco, 2012).

People who practice their lives with various creativity will change their lives to be more colorful, more passionate, and have an impact on themselves and others. The younger generation is the generation with the right time to cultivate creativity. A generation that has a passion for trying new things, a happy soul to create their own art creations. Anything will be interesting to try, develop, without fear of being wrong, dare to do something different from the usual, and continue to explore without stopping. The creative culture that was built from the start will encourage the younger generation to find new ideas and ways of doing things that are not the same, that are unusual, that are not similar, that are slightly different or very different until even banal ones are possible, in the name of creativity. Creativity is the basic thing that 
must be owned and trained so that life can continue to be developed to be more valuable, more useful, humans can improve themselves with new findings of great value.

Human creative ability is the ability that helps him to be able to do more than rational possibilities from the data and knowledge he has (Tabrani, 2006). Tabrani's opinion does not seem much different from that of Stein Morris I, who describes creativity as a thin threshold like a porous membrane that is easy to pass, move here and there, very flexible both intellectually and emotionally. Stein reported data from artists and chemists and concluded that creativity benefits from permeable cognitive structures, "for persons in one area (physics, for example) it may mean greater flexibility in the intellectual sphere, while for other... the artist, it appears as a greater flexibility in the emotional or affective sphere" (Runco, 1953).

Some decorative sandals like patchwork sandals, ribbon sandals, and rabbit-shaped decorative sandals below are examples of developing creative ideas that can be continuously explored into unlimited colors, shapes, and compositions. Anything can be a source of ideas that can be gleaned and become the basis for endless exploration. Training from various waste materials that accumulate a lot and over time tend to be damaged, then disposed of as waste has become a damaging environmental burden. The fashion industry is one of the largest contributors of waste to the environment, it is our concern to care and act to reduce fashion waste which continues to grow (https://insidepontianak.com/2019/11/05/industri-fashion-salah-satupenyumbang-limbah-terbesar/).

The approach by disseminating information about the utilization of textile waste, patchwork, and sorting textiles into used products that are needed by the wider community is a high-value solution. Not only increasing creativity but also educating the younger generation to care about environmental issues, be creative, have an entrepreneurial perspective, and have the spirit to build community welfare. 


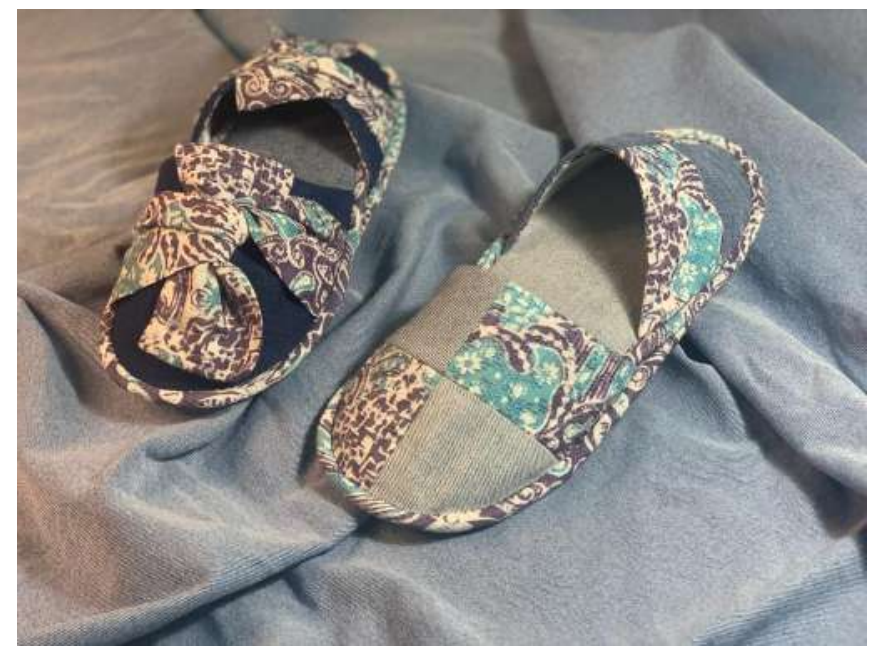

(source: Indra Janti documentation)

Fig. 1. Through the creativity of patchwork and ribbon sandals leftover textiles/sorting good can be reused into products that are needed by the community

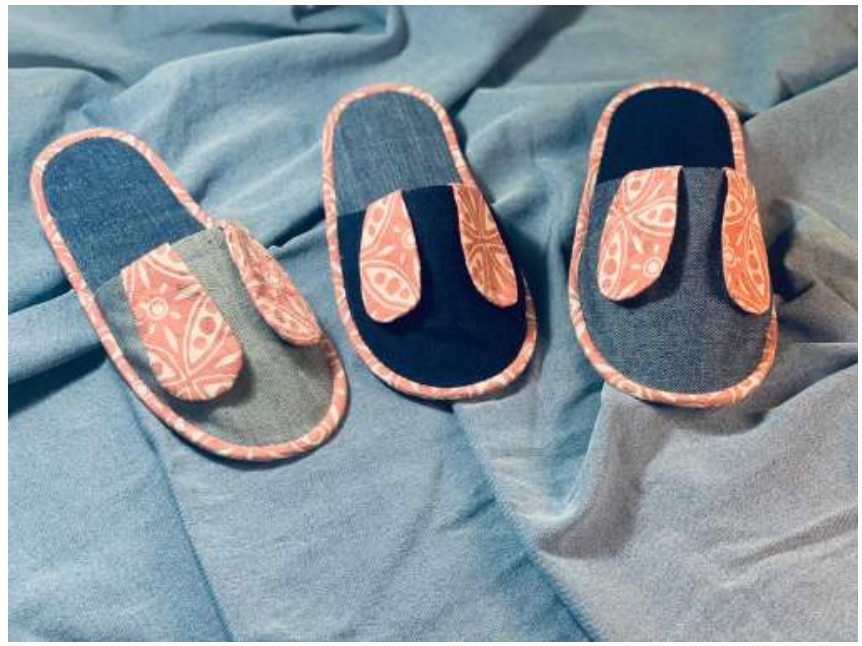

(source: Indra Janti documentation)

Fig. 2. Rabbit-shaped decorative sandals, various color, and fabric textures combinations

Decorative sandals made from textiles are sandals that are common home use so that the house is kept clean. They are replacement footwear after we wear sandals or formal shoes when we go out of the house. Slippers are made looser with more general sizes, so they can be used for men and women of all ages because of their standard shape. Feet need lighter and more exposed footwear after outdoor activities with tight and more closed footwear. Home slippers are always provided for visitors to five-star hotels in order to provide comfort for the stay and keep the bedroom clean from dust brought in from outside. Hotel sandals come with a standard shape, EVA sponge material without a textile layer as a wrapper, just to fulfill functional needs. Generally, hotel sandals with standard models without textile lining, are portrayed in Figure 3. 


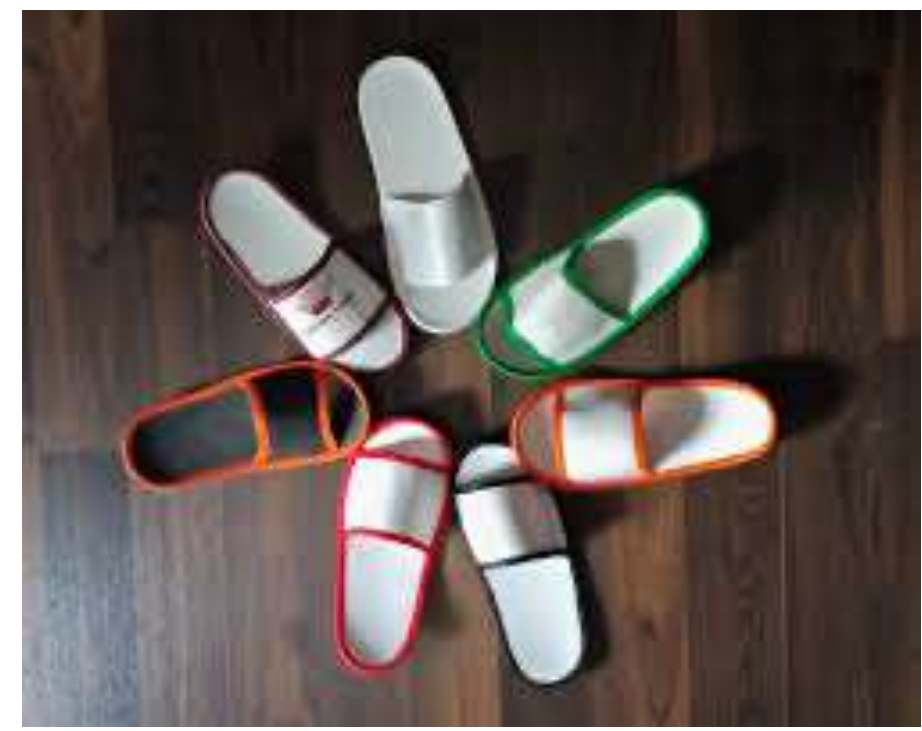

(source: https://www.google.com/imgres?imgurl=https\%3A\%2F\%2Fsuppliersendalhotel.com)

Fig. 3. Hotel sandals with standard model without textile lining

The house slippers which were carried out during the Karang Taruna community training were made by emphasizing the creative side as well as the functional side. Sandals are selected using textile materials as an outer layer to provide comfort for the feet and processed shapes that can be varied for aesthetic appeal. Decorative sandals with textile lining appear more stylish, more comfortable to wear on the feet, and durable because they can be washed. The participants could explore various variations of sandal toping on their own so that they found a wealth of shapes, color combinations, beautiful cuts, accessories, and textile designs that could be added. The materials used are selected from used materials or production waste materials such as sorting textiles, patchwork textiles from garments, clothing factory, or tailoring. Some of the photos below give an idea of the abundance of leftover fabrics and production waste, as garment or clothing factory waste and sorted textiles. 


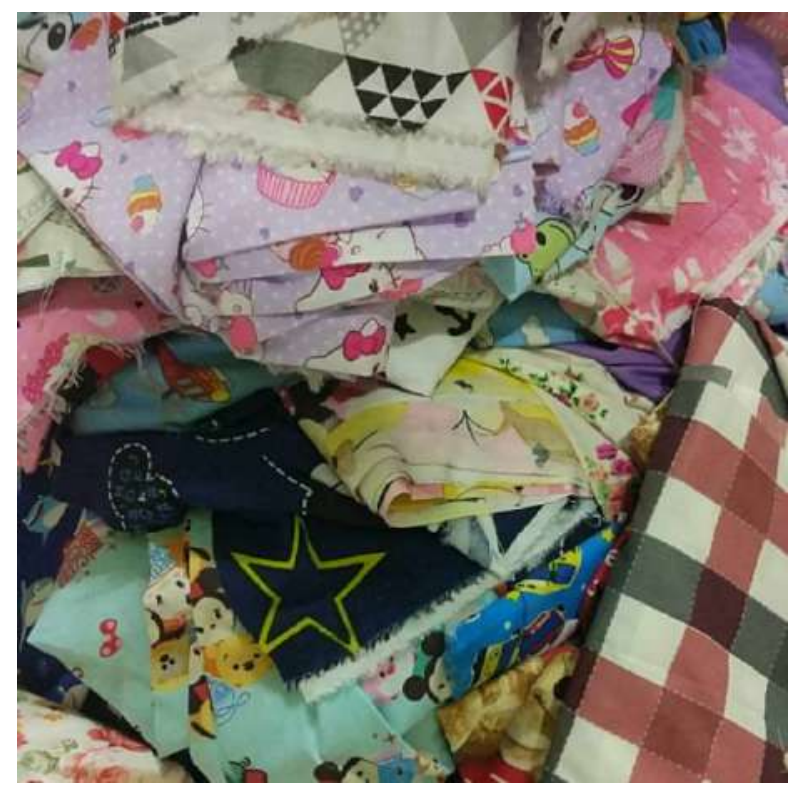

(source: https://shopee.co.id/PROMO-!!-Kain-PERCA-KAIN-CRAFT-KAIN-KILOAN-KAIN-KATUNPERCA-UNTUK-KERAJINAN-TANGAN-i.7636189.106822291)

Fig. 4. Textile waste or production waste such as garment, clothing factory or tailoring

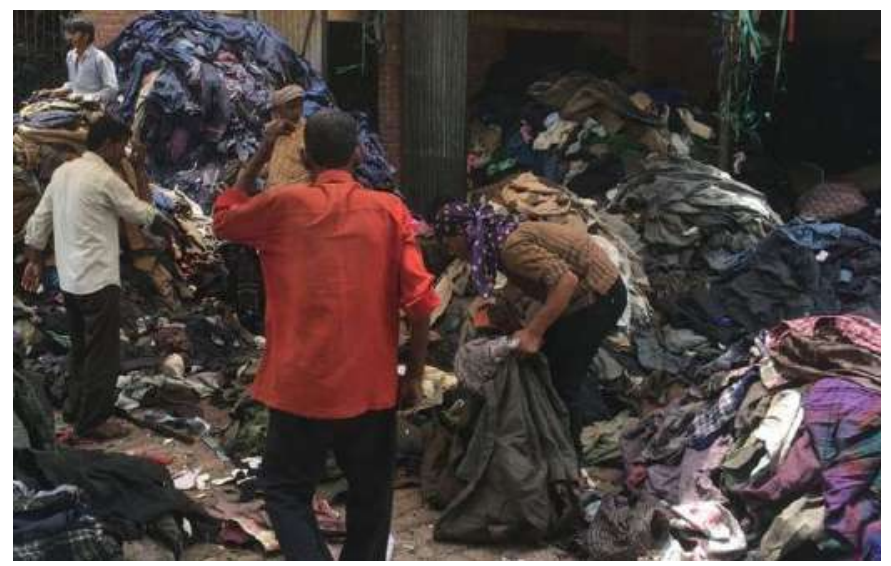

(source: https://ichef.bbci.co.uk/news/800/cpsprodpb/13E17/production/_96913418_clothes2.jpg)

Fig. 5. BS/Sorted Goods/Wrong-measured clothes, production leftovers, unsold garments

Leftover denim and sorted textile at home and in the industry can be reused into useful disposable items. Lecturers and students can practice and share their expertise directly with the user community so that the transfer of knowledge is right on target, opening up opportunities for collaboration and socializing with the user community and industry. The photo below describes the transfer of knowledge made by a lecturer to the user community. Industry parties who have leftover fabrics that are not useful in the warehouse will be very open to cooperation if there are parties who can use them for non-governmental efforts. 


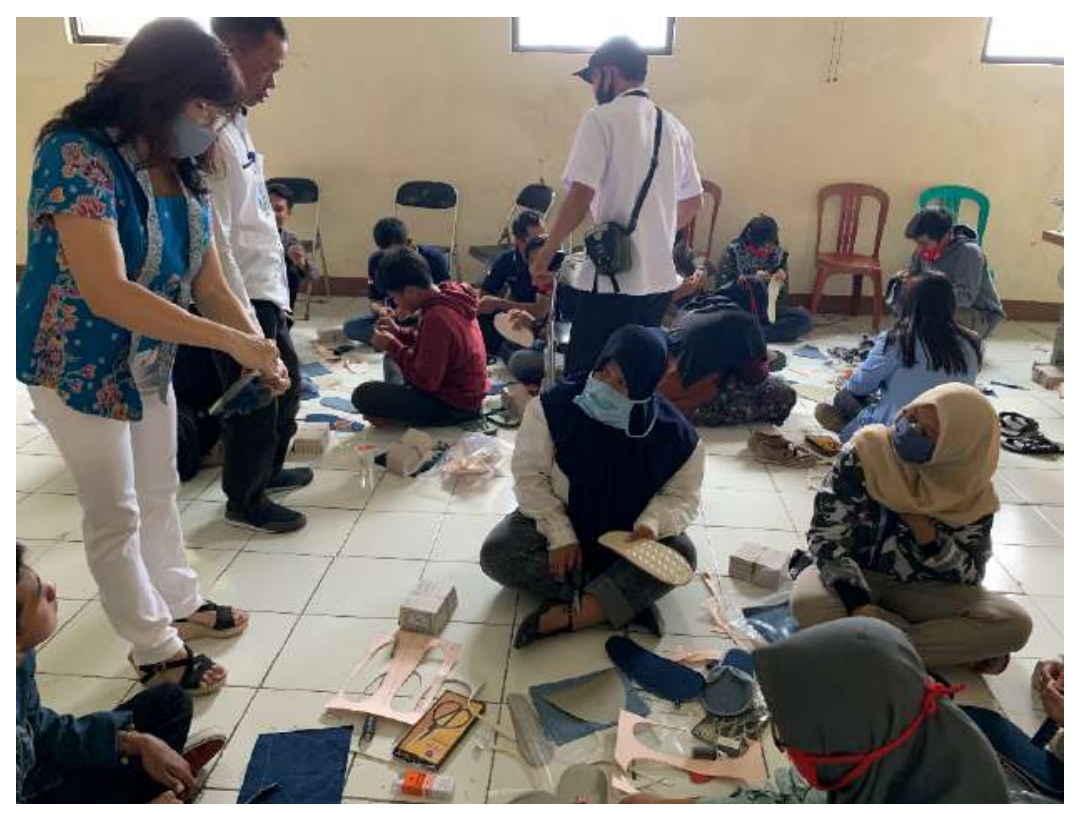

(source: documentation of diploma III fashion design study program)

Fig. 6 Lecturers and students can socialize and share knowledge

\section{Methods}

The method used in this training is the participation of trainees in practicing and making decorative sandals, following modules that are taught both online and onsite. The method is known as Community Based Participatory Research method. It doesn't focus on formal arrangement but gives opportunities for each other to participate (Majidah et al, 2021). The training was carried out by lecturers and students in a demonstrative manner and then followed by participants in its implementation by directly applying the steps taught. The training was carried out in a hybrid manner, both online and onsite due to the pandemic condition, for 5 meeting days in 5 weeks. The length of time allowed the participants to be able to take part in the training well, to be able to explore other styles of sandals in a creative and interesting way. Some participants were able to create some very inspiring works, so during the training, several works were ordered and purchased during the exhibition as the results of the training on the last day.

Karang Taruna community is then encouraged to develop it into a sustainable production business. The availability of several sewing machines at Balai Karang Taruna Bojonghaleuang and the abundance of waste and reject textile raw materials in Bandung are capital and opportunities to realize these efforts. The trainees can continue to re-explore the sandal model in other, more attractive forms, according to their respective creativity or according to the 
wishes of the customer, and can then meet the market's tastes. Chronologically the method is carried out as follows:

1. Tutorial

a. The material was given with a short presentation by the Diploma III Fashion Design lecturer covering the background of the use of textile waste in the form of used clothes, production scraps with the aim of reducing fashion product waste.

b. The selection of appropriate materials, namely strong and thick fibrous fabrics.

c. Transfer of patterns using the sandals that we wear.

d. Making patterns with various designs and the process of making sandals were explained by the lecturer of Diploma III Fashion Design.

The photo below describes the lecturer's presentation to the user community.

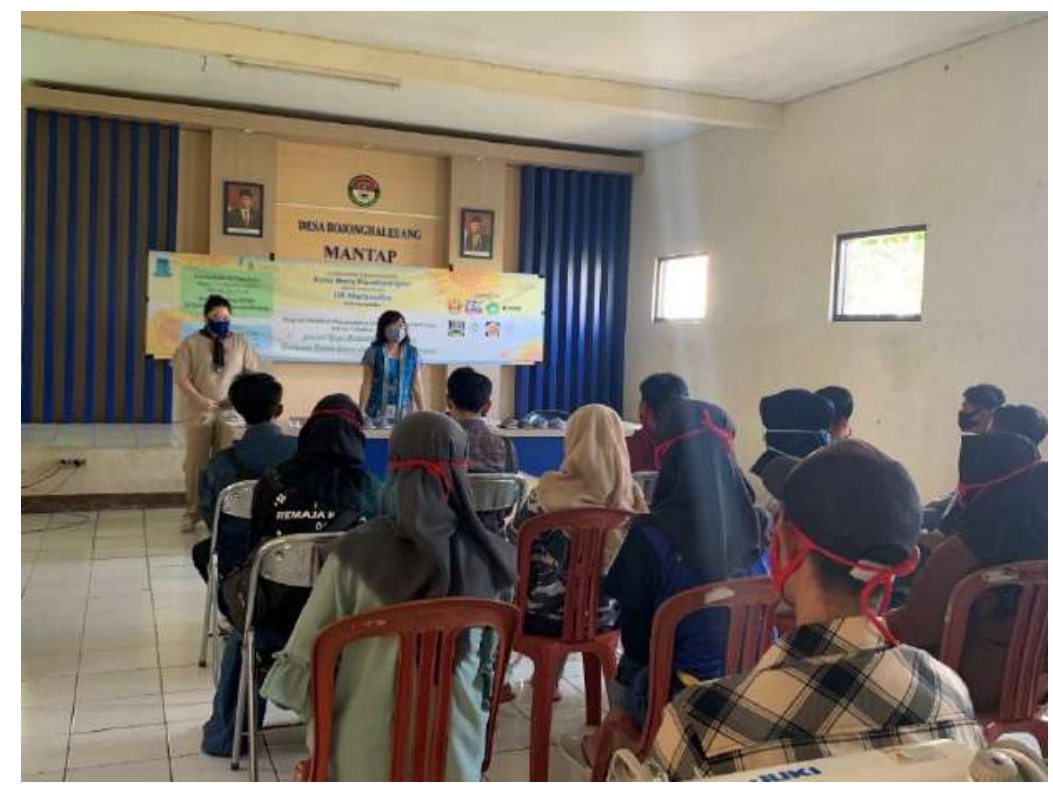

(source: documentation of diploma III fashion design study program)

Fig. 7. Tutorial presentation

2. Studying Module

a. The module was given as a guide for service participants to make it easier to understand the process of making decorative sandals. Participants received direct instruction on sandal pattern models, including training materials in the form of leftover textiles, EVA sponge for sandal soles, sewing thread, needles, and scissors on the first day of training.

b. The next training was carried out online, things that were not understood related to the process could be asked at the next online meeting or by private messages to the lecturers or students via WhatsApp. 
c. Knowledge improvement of the participants was assisted by a tutorial presentation using a youtube video tutorial on the process of making decorative sandals from lecturer Tan Indra Janti with the link: https://youtu.be/Bhe-Y9DP18Q. Participants can watch the manufacturing process themselves with the help of videos when they do not receive faceto-face guidance.

The study modules provided include three different types of cutting and sewing techniques: Decorative Tie Ribbon Sandals, Decorative Patchwork Sandals, and Rabbit-shaped Decorative Sandals. The following is a visual illustration of one of the modules given in this activity, a decorative Tie Ribbon Sandals Module:

Table 1. Decorative tie ribbon sandals module

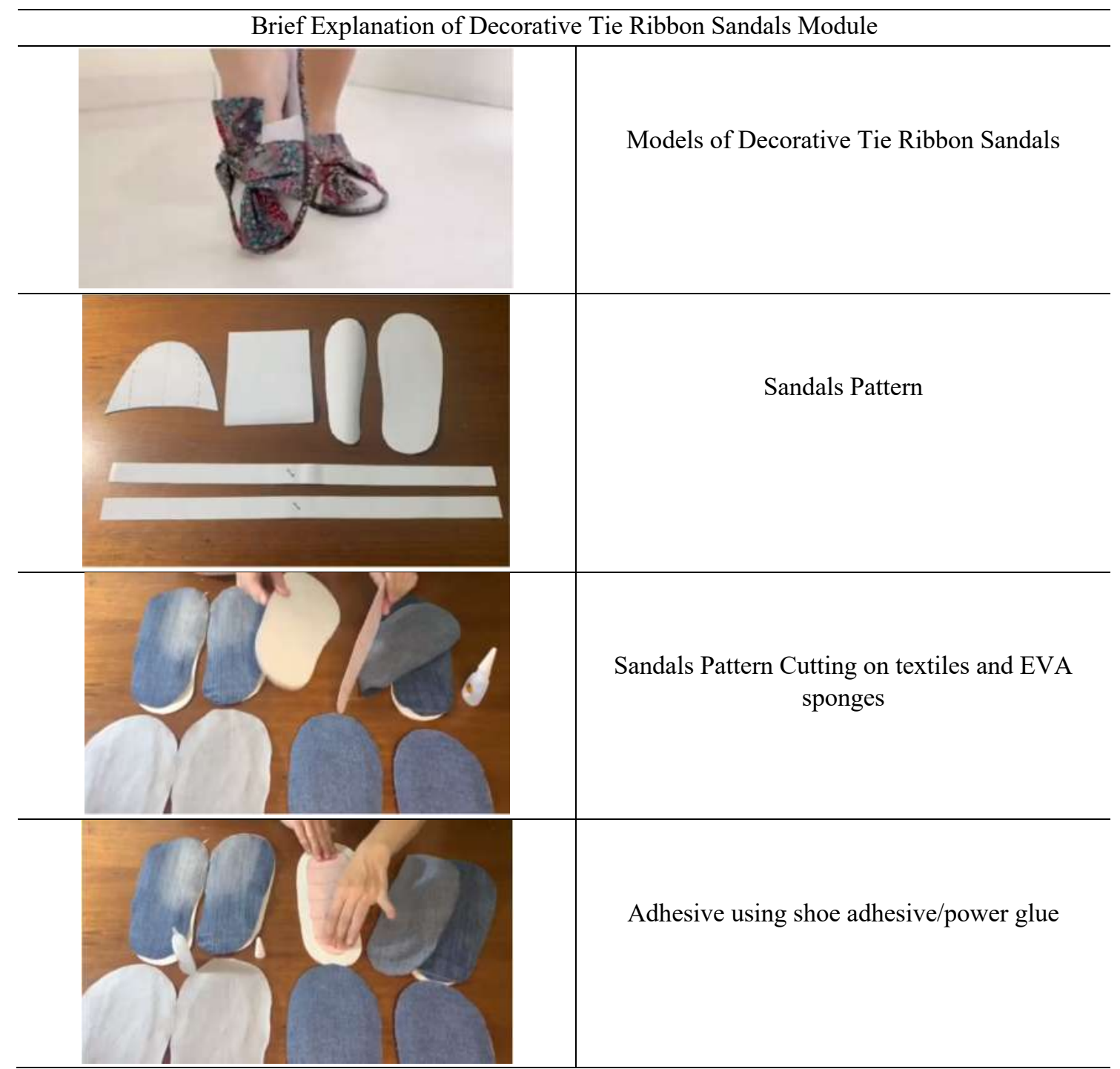




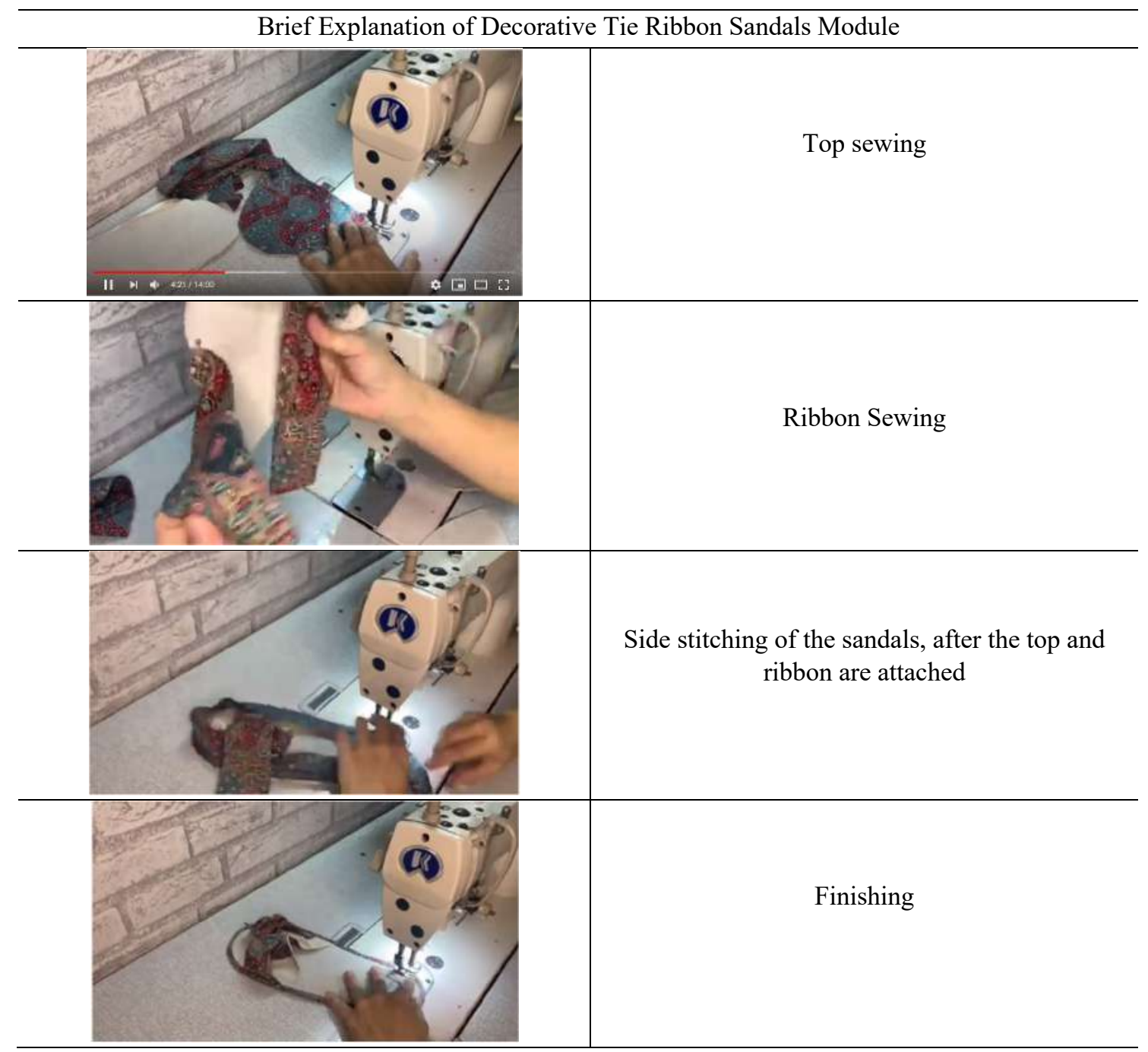

(source: https://youtu.be/Bhe-Y9DP18Q by Tan Indra Janti)

\section{Results and Discussions}

The discussion of the process and results of the development of Sandal Gaya recycled materials in the youth community in Bojonghaleuang village, West Bandung district can be explained as follows:

\section{Sewing}

a. Selection of Patchwork

The exploration process began with the selection of thick-textured textile materials for the base and the rest of the textile/patchwork that has been provided by the Diploma III Fashion Design Study Program as decoration. The lecturer and students gave directions to the participants how to mix and match various types of leftover fabrics. Starting from the type of fabric, the thickness of the fabric, the color, the texture, the arrangement of the stitching lines, and others. The participants are advised to sort and clean the leftover 
cloth before sewing or before trying it, outside of this service activity. Optimal results also depend on choosing a good and clean material at the beginning before cutting it in the form of sandal patterns. The activity of the material selection, cutting, and sewing of sandal patterns according to the creativity carried out by each participant can be seen as follows:

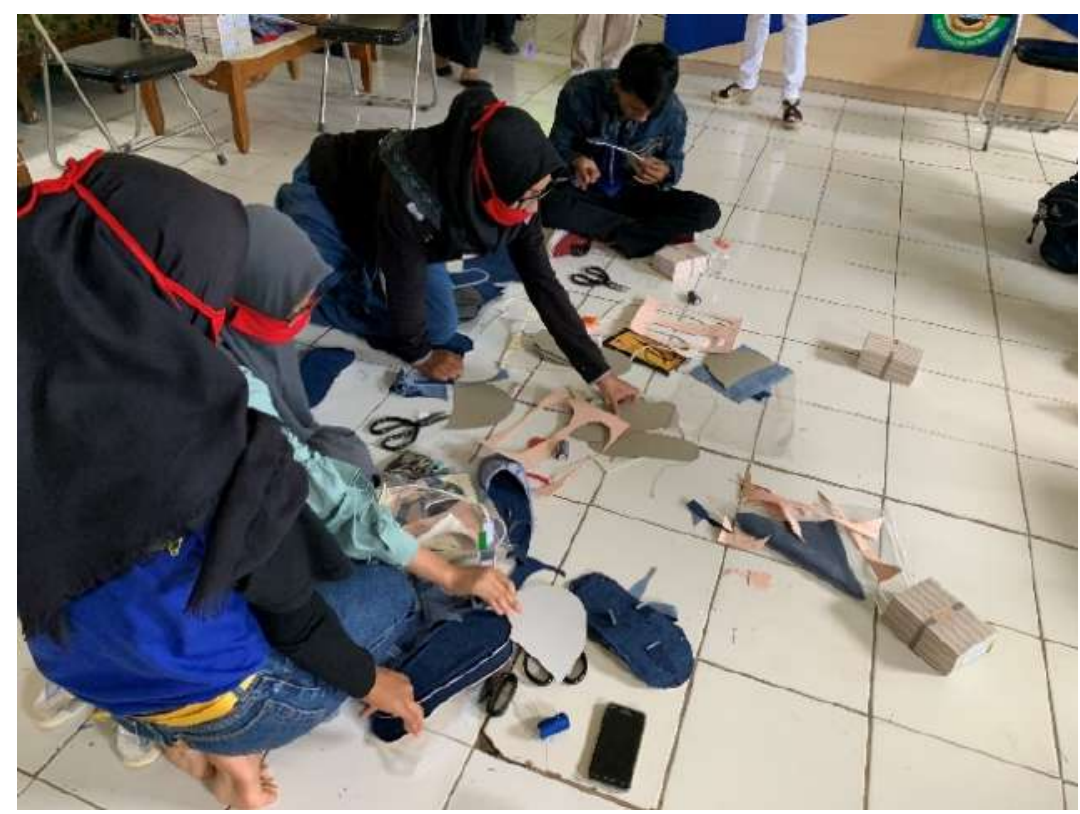

(source: documentation of diploma III fashion design study program)

Fig. 8. Material selection and pattern cutting

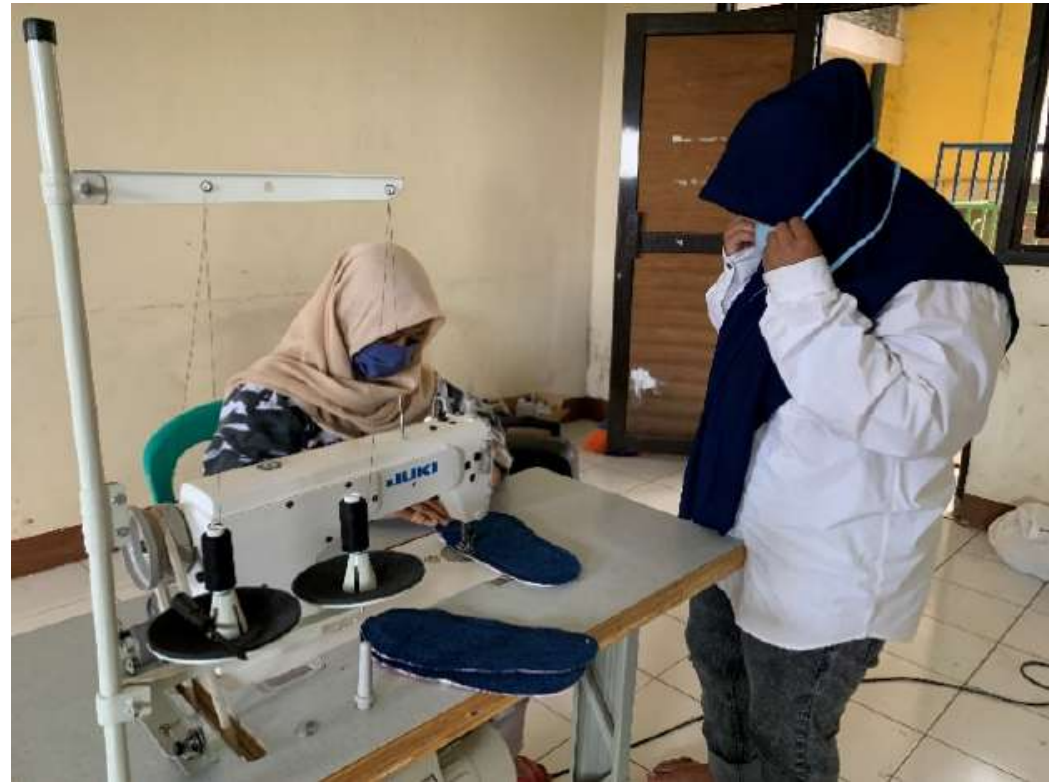

(source: documentation of diploma III fashion design study program)

Fig. 9. Pattern sewing 
The patchwork provided was leftover fabric from the past Pattern and Sewing Class Subject from Fashion Design Study Program. This could be one of the ways to reduce textile waste generated in the garment production process (Pratiwi, 2021). The leftovers were collected or bought in the market by weighing it instead of using a meter scale. The price of leftover fabric that still can be used, is cheap and affordable, and is a good way of reusing materials that are no longer needed. At least this community service helps realize the world's call to go green against the waste that is produced by the fashion industry.

b. Selection of Cutting Techniques and Sewing Techniques

In addition to following the training module, participants were allowed to be creative freely in determining the desired decorative sandal design. The teacher provided several techniques for breaking the sandal topping pattern to be applied to the design desired by each participant. This can be seen from the Youtube video link given above.

c. Lecturers and students also guided the participants to operate the sewing machine correctly and durably, about things related to the operation of the machine such as threading, machine shoes, reverse sewing, ways to fix the machine when the thread is tangled or when the needle is broken. Patrticipants was trained from making the basic pattern of sandals, selecting threads and sewing aids (scissors, tape measure, chalk, fabric ruler and others), adding additional decorations such as toptitchs, embroidery, buckles, to finishing details.

2. Finishing Process

Participants were given the freedom but also direction in making attractive sandal designs. Various elements of decoration could be explored by getting the guidance from the lecturers and students such as about embroidery, application additions, lettering, color combinations, fabric ties, edge stitching etc. The following Table 2 shows decorative sandals creation from exploration that had been carried out by participants who prioritize their personal creativity. 
Tabel 2. Beautiful sandals creation exploration

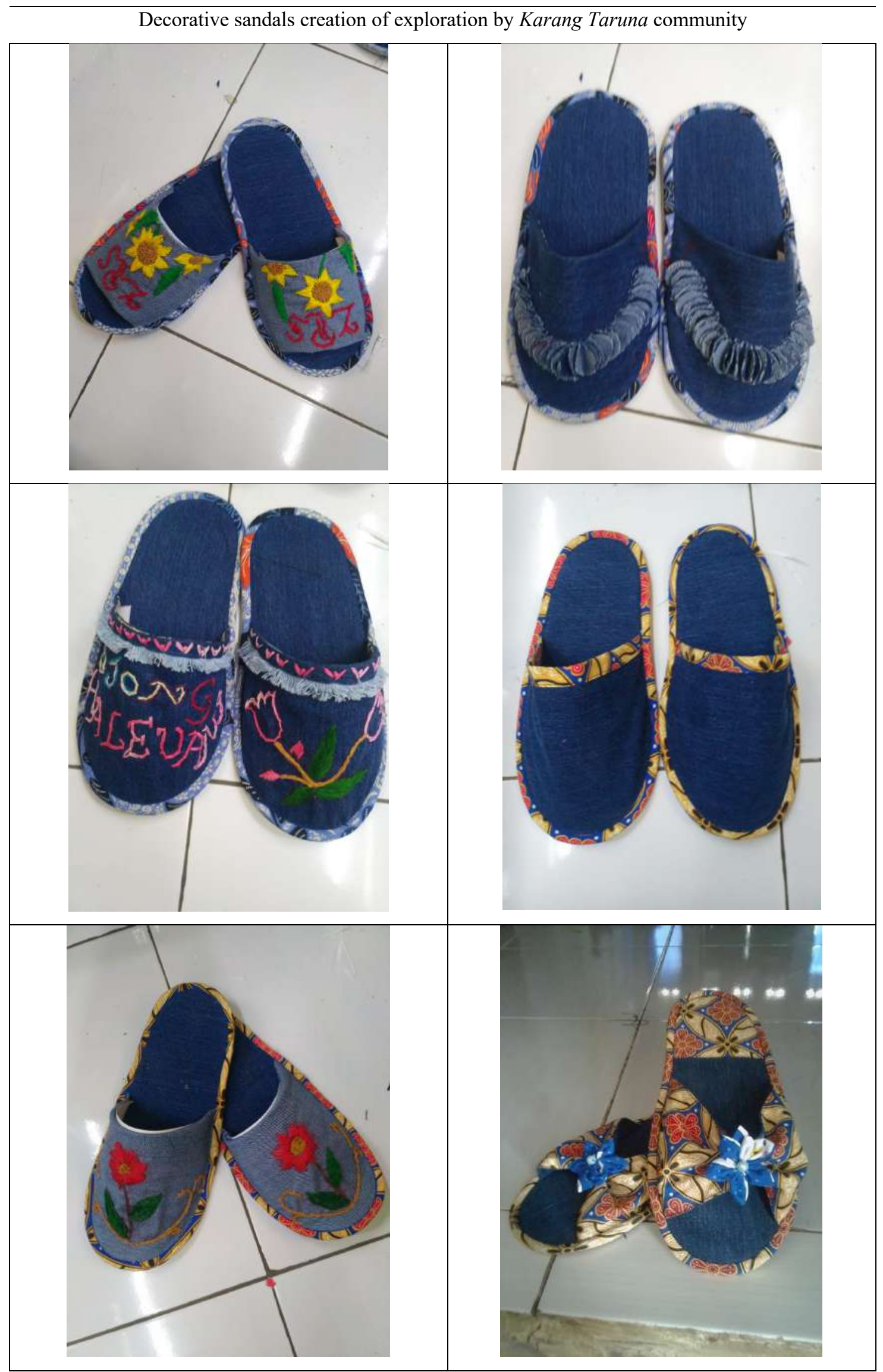

(source: documentation of diploma III fashion design study program) 
3. Friendly and Group Photos

This activity happened on the last day of the training when the process of making decorative sandals was completed, followed by a closing ceremony for the community empowerment activities, greetings, and thanks from those who took part in this event. The event was closed with the distribution of souvenirs for 3 participants with the best and warm-hearted work and then a group photo session. However, each of the participants still got a certificate as an award for his or her participation in the activity. The photos below explain the situation of selecting the best works and awarding certificates to participant.

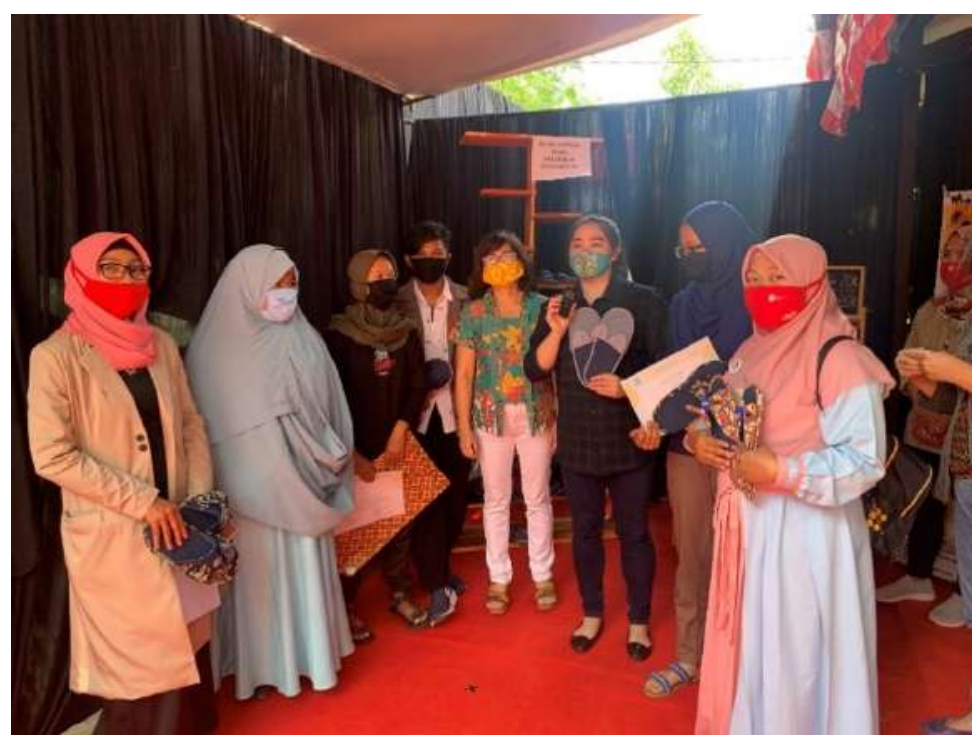

(source: documentation of diploma III fashion design study program)

Fig. 10. Best work selection briefing giving certificates to participants

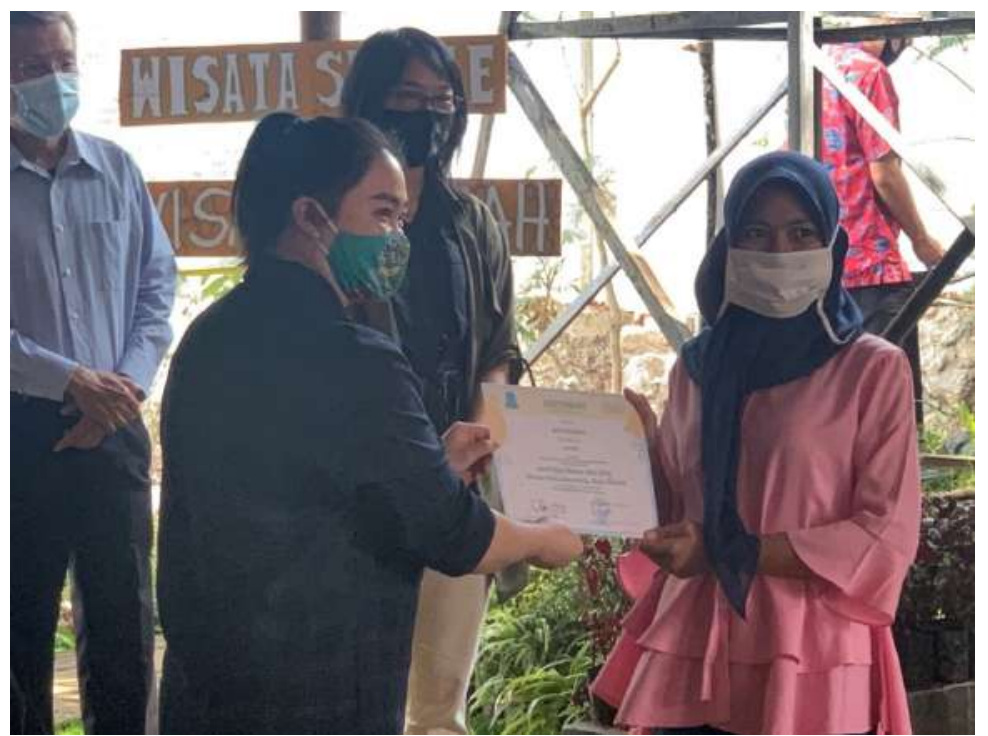

(source: documentation of diploma III fashion design study program)

Fig. 11. Giving certificates to participants 
There was also a group photo session of the lecturers, students and participants who won the best work. The lecturer captured the success of all service activities on September 10, 2020 at the sunflower plantation which is located behind the Kube workshop and the Bojonghaleuang Village Office.

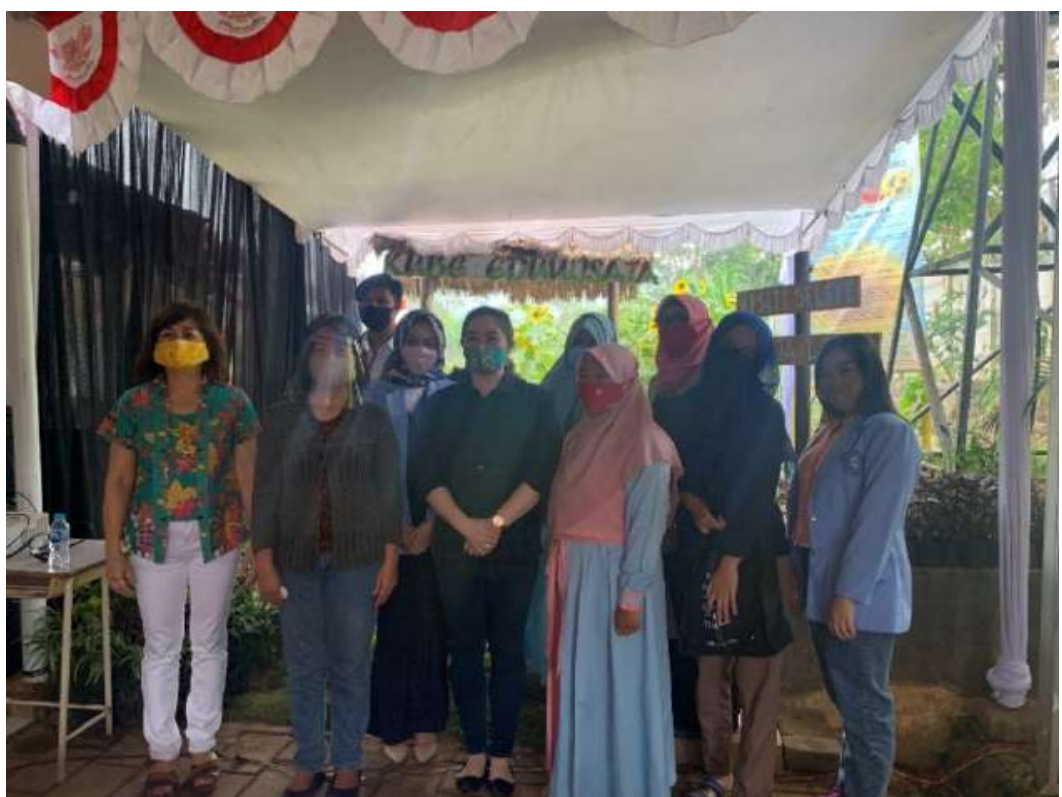

(source: documentation of diploma art and design program, faculty of art and design)

Fig. 12. Joint photo of the winners of the best decorative sandals, lecturers, and students

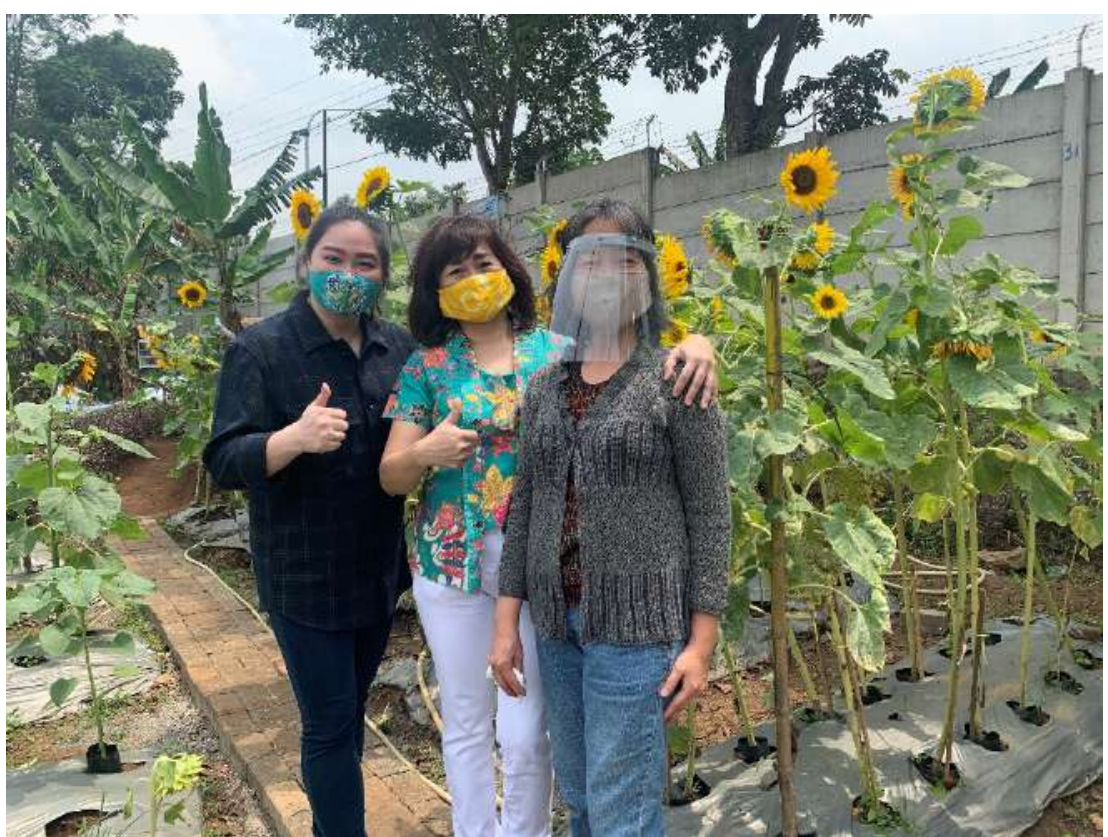

(source: documentation of diploma art and design program, faculty of art and design)

Fig. 13. Lecturers for decorative sandals Wenny, Yanti, and Lois (start from left) 


\section{Conclusion}

Community empowerment activities with the theme of Development of Recycled Material Style Sandals at the Karang Taruna Community, Bojonghaleuang Village, West Bandung Regency, have gone well and have had a positive impact. Skills empowerment has provided assistance to young people in developing creativity in making various stylish sandals that are beautiful and popular with the community. This empowerment activity stimulates young people to be self-sufficient which is useful not only to improve skills but also to open up insights and opportunities for entrepreneurship. This paper explains the contribution that can be made by lecturers and students Diploma of Art and Design, Faculty of Art and Design in the form of spreading community skills empowerment. Implementation of the acquired skills can be developed to produce competitive products. Service activities can also be continued in the form of assistance in collecting reused textile materials, design development, production processes, calculating selling prices and marketing.

Stylish sandals are not only for personal use at home but can also be produced for the needs of this ever-growing lodging business that requires room sandals for hotel visitors. Utilization of leftover garments, production residues, and the abundant sorting of leftover clothes in Bandung is a very appropriate solution because they tend to become waste and cause environmental problems. On the one hand, the empowerment of stylish sandals can become a commodity business that is needed by the community, on the other hand, the basic materials using leftover fabrics have a positive impact in restoring environmental sustainability. Such conditions are certainly ideal if home industries can be pursued that can produce products needed by the community while at the same time improving the quality of a sustainable living environment.

\section{Acknowledgements}

Our gratitude goes to the Karang Taruna Community in Bojonghaleuang Village, Bandung Regency and Mr. Ryan Brasali as Director of Kota Baru Parahyangan for providing opportunities for lecturers and students of Diploma III Fashion Design, Faculty of Fine Arts and Design, Maranatha Christian University to carry out Community Empowerment Activities. Service activities are part of the duties of lecturers in carrying out the Tri Dharma of Higher Education, with the implementation of these service activities, the obligations of lecturers can be fulfilled properly. 


\section{References}

https://youtu.be/Bhe-Y9DP18Q.

https://insidepontianak.com/2019/1 1/05/industri-fashion-salah-satu-penyumbang-limbahterbesar/

Lubart, Todd. (2016). Creativity And Convergent Thinking: Reflections, Connections And Practical Consideration. RUDN Journal of Psychology And Pedagogics. p. DOI: 10.22363/2313-1683-2016-4-7-15

Majidah, Cahyaningsih, Saraswati, R.S., Inawati, W.A. (2021). Self-Identification of Homestay Management Problems and Canvas Busines Model, Journal of Innovation and Community Engagement (Journal of ICE), Vol 2, No.1, p.3

Pratiwi, Ni Putu Ekawahyu (2021): Pemanfaatan Kain Perca Bagi Penjahit Putri Guna Meningkatkan Omset di Tengah Pandemi Covid-19 di Desa Padangsambian Klod, Journal Parta, Vol.2, No.1, p.43.

Runco, Mark A and Jaeger, Garrett J. (2012). The Standard Definition of creativity. Creativity Research Journal, Comments and Corrections. p. 95. DOI419.2012.650092

Tabrani, Primadi (2006). Kreativitas \& Humanitas. Jalasutera. Yogyakarta. 